\title{
The Relation of Academic Advisor and Quality of Learning Skills Toward Student Learning Achievement of Counseling Guidance Study Program
}

\author{
Alfi Rahmi ${ }^{1}$, Yasrial Chandra ${ }^{2}$, Rahmawati Wae ${ }^{3}$, Januar $^{4}$ \\ \{alfi.rahmi79@gmail.com ${ }^{1}$, chandrayasrial@gmail.com ${ }^{2}$, rahmawae89@gmail.com ${ }^{3}$, \\ eljanuar78@gmail.com ${ }^{4}$ \} \\ Institut Agama Islam Negeri (IAIN) Bukittinggi, Indonesia ${ }^{1,3,4}$ \\ Programme of Study Guidance and Counseling Padang, Indonesia ${ }^{2}$
}

\begin{abstract}
Academic Advisors have essential duties and functions to help students to achieve good learning performance. In addition, improving students' learning performance can also be influenced by mastering good learning skills. The problem is not all academic advisors carry out their duties and functions as specified in academic guidelines, as result there are students who have low learning achievement. The purpose of this research is to find the relation between academic guidance conducted by academic advisors toward student achievement and the quality of students learning skills. This type of research is quantitative correlation. The population in this study was BK study program students for the year of 2017. The results showed that the relationship between academic guidance and learning skills on learning achievement with a correlation coefficient of 0.127 , this indicates a weak correlation.
\end{abstract}

Keyword. Academic Advisor, Quality of Learning, Learning Achievement

\section{Introduction}

Higher educational institutions such as collage and university play an important role in national development. It has the task to create experts who have high knowledge and are able to develop their knowledge through technology and information that is beneficial to national development. Someone who wants to be a student whose job is studying in college must understand and be aware that he will face the scientific world. Implementation of higher educational insitution aims to prepare its students to face the workforce and prepare them to be able to interact and minggle with the society. This is in line with article 2 of Government Regulation Number 60 of 1999 as follows:

1. Preparing students to be members of the community who have academic and / or professional skills who can apply, develop and / or create technological knowledge and / or art.

2. Developing and disseminating knowledge, technology and / or arts and striving for their use to improve people's lives and enrich national culture.

In order to support the implementation of academic education as stated in the government regulations above, the institution of higher educational institution has work units that have 
functions and roles for the development of academic activities. One of the essential work units is the study program. The study program has a curriculum that is a benchmark for student success marked by graduate competency standards. Achieving student competency in accordance with graduate competency standards, the study program has lecturers as teaching staff and as student academic advisors.

Academic Advisor is a lecturer who has an advisory role for his students regarding academic progress. [1]. The task of being an academicadvisor is an additional task for lecturers to guide and motivate students to have skills in learning to achieve success in studies. According to A Muri Yusuf that the role of academicadvisor is to help students prepare themselves before, during and after lectures so that students are ready to face the lectures, ready to follow the lecture process and ready to end the lectures by taking the final exam. [2]

Quality academic advising as a multidimensional process encompassing five domains: provision of accurate information about degree requirements and how the institution works within time lines, policies, and procedures; referral to campus resources for academic and nonacademic problems; integration of the student's academic, career, and life goals with each other and with aspects of the curriculum and cocurriculum; individuation, or consideration of students' individual characteristics, interests, and skills; and shared responsibility or encouragement of students to assume responsibility for their education by giving them opportunities to develop and practice planning, problem-solving, and decision-making skills(Smith \& Allen, 2006). To design our cognitive outcomes, we focused explicitly on three of these domains: information, referral, and integration.(Allen 2014)

One of the students' ability in preparing the right study plan is to have the right learning skills so that it will produce learning achievements with a high achievement index. The problems that happen related to the implementation of this academic advisory role at Faculty of Tarbiyah and Teacher Training of State Islamic Institute ofBukittinggi especially in the counseling guidancestudy program that not all academic advisors provide intensive time to foster guidance for students, and the same goes to students who only meet thier academic advisors only to ask the study plan approval, and do not consult in order toovercom their problems. This condition will have an impact on students' learning achievement.The purpose of this study is to look at the role of academic advisors by academic advisors in improving the quality of learning skills and student achievement in the 2017 class of guidance and counseling study program.

\section{Review Of related Theory}

\subsection{Academic Advisor}

Academic advisors are lecturers who have an advisory role for students to help students to be succeed in their studies. Academic advisors are recognized as important to student progress. Advisors are defined as being resource persons, referral agents, student advocates, and friends[3]. This advisory is an additional task which is charged to the teaching staff of the university in addition to carrying out its main tasks. According to A. Muri Yusuf, academic advisors have a role to help students prepare before, during and after lectures, so students are ready to face lectures, ready to end their lectures by taking final exams [4]. Based on the Faculty of Tarbiyah and Teacher Training of State Islamic Isntitute of Bukittinggi academic guidebook stated that academic advisors are appointed lecturers who are given the task toguide 
a group of students that has aimed to help students complete their studies as efficiently as possible in accordance with the conditions and potential of individual students. [5]

The academicadvisor has several taskas following: (Bukittinggi, 2019)

1. Giving appropriate direction to students in preparing programs and study plans and in choosing courses to be taken.

2. Helping students to overcome the problems of their studies experienced

3. Writing down recommendations and initialing each time after conducting guidance at the time of guidance that has been provided for each student.

4. Giving recommendations on the level of success of student studies for certain purposes, including in the process of study evaluation for academic coaching or the determination of study dropouts or study dropouts to the head of the study program.

5. Academic advisors are required to provide periodic guidance during the student's study period, a minimum of 4 (four) times consisting of two academic guidance and two nonacademic guidance in one semester and recording it in an academic guidance card.

6. Academic advisors are required to provide Extra Curricular guidance as evidenced by evidence of participating in activities that done in outclass every semester and join the lectures.

Learning goals are imbedded most clearly in the institution's mission statement and related documents. Helping students understand the purpose and values of the institution is critical to their understanding the purpose of college. Our analysis of common threads in college mission statements led us to identify the first organizing principle for the advising curriculum (Hemwall\&Trachte, 2003, pp. 13-14):[6]:

1. Principle 1 Academic advising should facilitate student learning about the mission of the college.

2. Principle 2 Academic advising should facilitate student learning of both lower- and higher-order thinking skills

3. Principle 3 Academic advising should facilitate student learning about the means of achieving the goals imbedded in the institution's mission statement and closely related documents.

These three organizing principles lay the groundwork for a curriculum for academic advising. They help advisees identify the goals and values of the institution through the mission statements and related documents, to push advisees to develop higher-order thinking skills, and to assist student learning about how to achieve institutional and personal goals.

\subsection{The Quality of Student Learning Skills}

Studying in highereducational institution is a specific activity because students are considered as a person who alreadymature in physically and psychologically and are considered as a person who alreadyindependent. The way to study in tertiaryis different from the way of studying in secondary school becausethe campus is characterized by a scientific atmosphere and logical thinking. The student learning system in higher education is known as the Semester Credit System. To undergo the semester credit system well, students need to have skills in learning. According to KarmidiMartoatmojo in YahyaGanda mentioned that learning skills are the ability to quickly learn new things. Naturally adequate facilities will more or less encourage the creation of learning skills, but regardless of desire and high will is the most important.

According to Prayitno, there are three successes indication of study. Prayitno explained that students are expected to achieve three successes namely academic success, career planning success and social success.[1].This is the following i explanation of each of these successes: 
a) Academic success, refers to the success of students in their lectures, since the first semester until the graduation. This success refers to the values of student learning outcomes symbolized by the achievement of and point grade average (GPA). The academic success of students is also marked by the short period of study they use to complete college, so that they can graduate on time. Academic success is not only supported by high intelligence, but by many things including the ability to learn and the problem solving done by the students to solve various problems that interfere with their development, life and learning activities during their studies. In another words, intelligence also needs to be considered is the ability to learn and alleviate student problems.

b) The Success of careerplanning, is a success thateffectsstudents' future, that is after completing studies, college graduates have good enough preparation so that they are expected to have the workforce immediately. The fact shows that very few college graduates can immediately pursue a career in accordance with the department or study program that they participated in immediately after graduation. Most of them actually have to wait long enough to be able to have the appropriate career. While waiting for the appropriate careers, they have the opportunity to tryanother kind of careers that still allow the practice of the study programs they have mastered, oranother kind of career that demand other abilities.

c) Social Success, success that should integrateed with academic success and career planning success. The application of academic abilities and career abilities are inevitably takes place in certain conditions of social relations. The social relations will give color, and even determine the success of the application of the two previous successes. Social success also does not come automatically, but requires coaching. Fostering social relations of students is a mandatory completeness adapted to fostering academic ability and career planning

\subsection{Learning Achievement}

Achievement is the result of an activity that has been done, created both individually and in groups. One of the activities carried out is learning. In the learning process will involve a variety of learning activities that has a result in changes of behavior. Changes in behavior is a learning outcomes that also stated by Mulyasa in Istarani and IntanPulunganwhere the characteristics of behavior as learning outcomes are[7]

a. Changes in learning outcomes behavior are intentional,it means that the experience or practice of the exercise was deliberately and consciously carried out not by accident.

b. Changes in learning behavior are positive meaning that is expected.

c. Changesbehavior in learning as an outcomesis effective if that changes in learning outcomes are relatively fixed and can be used in problem solving.

Measures which assess student achievement in terms of a criterion standard provide information as to the degree of competence attained by a particular student which is independent of reference to the performance of others." Achievement measures may also convey information about the capability of a student compared with the capability of other students. Achievement tests are used (a) to provide information about the characteristics of an individual's present behavior and (b) to provide information about the conditions or instructional treatments which produce that behavior. 


\section{Methodology}

This type of research is quantitative correlation. The research was conducted on the 2017 Counseling Guidance Study Program students. The 2017 class of population consist of 120 students.

Table 1. Amount of Students of conseling guidance study program in 2017 generation

\begin{tabular}{lll}
\hline No & Class & Amount \\
\hline 1 & Class A & 40 \\
2 & Class B & 40 \\
3 & Class C & 40 \\
4 & Amount & 120 \\
\hline
\end{tabular}

In taking samples, researchers used the taro yamane formula, as following below: (Riduwan, 2013)

Information:

$$
\mathrm{n}=\frac{\mathrm{N}}{\mathrm{N} \cdot \mathrm{d}^{2}+1}
$$

$\mathrm{n}=$ Sample

$\mathrm{N}=$ Population

$\mathrm{d}^{2}=$ leeway precision / inaccuracy due to sampling error is $10 \%$

Based on the calculation of the formula above, we obtained a sample of 54 people where the sample is random sampling technique, where random sampling without regard to strata in the population. (Sugiyono, 2018). Data collection techniques using the academic guidance questionnaire with indicators of the Academic Advisor's assignment, AUM PTSDL Part T (Learning Skills) and Student Achievement Index semester 4. Based on the results of the trial of the academic guidance questionnaire of 35 statement items after being tested on non-sample populations , 24 valid items are obtained.

\subsection{The Technique of Data Analysis}

\section{Normality Test}

The normality test conducted by the researcher uses the Kolmogorov test with the help of the SPSS version 22.00 program. If the significance value of correlation (sig) on the calculation result is greater than alpha $(0.05)$, then it can be said to be normally distributed. Conversely, if the significance correlation value (sig) on the calculation result is small from alpha (0.05), then it can be said to be not normally distributed. The normality test that the researchers got in the number of samples was 54 people using the SPSS version 22.00 as follows:

Table 2. Normality test quality in learning skills, academic guidance and achivement index

\begin{tabular}{lcccc}
\hline & \multicolumn{4}{c}{ One-Sample Kolmogorov-Smirnov Test } \\
$\mathrm{N}$ & & Quality & Guidance & Index Achievement \\
Normal Parameters ${ }^{\mathrm{a}, \mathrm{b}}$ & & 54 & 54 & 54 \\
& Mean & 42.1667 & 83.7611 & 3.2074 \\
Most Extreme Differences & Std. Deviation & 10.01838 & 12.65768 & .17781 \\
& Absolute & .115 & .115 & .087 \\
\hline
\end{tabular}




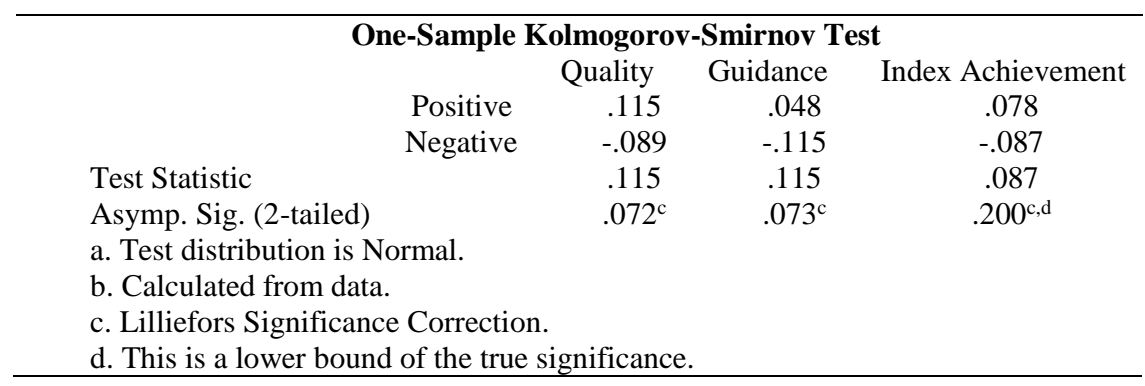

Based on the interpretation of SPSS version 22.00 for Windows for normality test, if the significant value of testing $>$ alpha (0.05), then the data is normally distributed. The three variables above test sig at> alpha (0.05), then the data is normally distributed.

2. Linearity Test

To find this data linear or not, it can be seen in the following linear test:

Table 2. Linearity test between index achivement and academic coaching

\begin{tabular}{|c|c|c|c|c|c|c|c|}
\hline \multicolumn{8}{|c|}{ ANOVA Table } \\
\hline & & & Sum of Squares & $\mathrm{df}$ & Mean Square & $\mathrm{F}$ & Sig. \\
\hline$\overline{\mathrm{IP} *}$ & Between & (Combined) & 1.018 & 37 & .028 & .670 & .845 \\
\hline Pembimb & Groups & Linearity & .023 & 1 & .023 & 548 & .470 \\
\hline ingan & & Deviation from Linearity & .996 & 36 & .028 & .673 & .841 \\
\hline & ithin Group & & .657 & 16 & .041 & & \\
\hline & Total & & 1.676 & 53 & & & \\
\hline
\end{tabular}

Based on the results of the linearity test, the sig value is known. $0.841>0.05$, it can be concluded that there is a linear relationship between IP and Academic Guidance.

Table 3. Linearity test between index achievement and quality of lerning skills

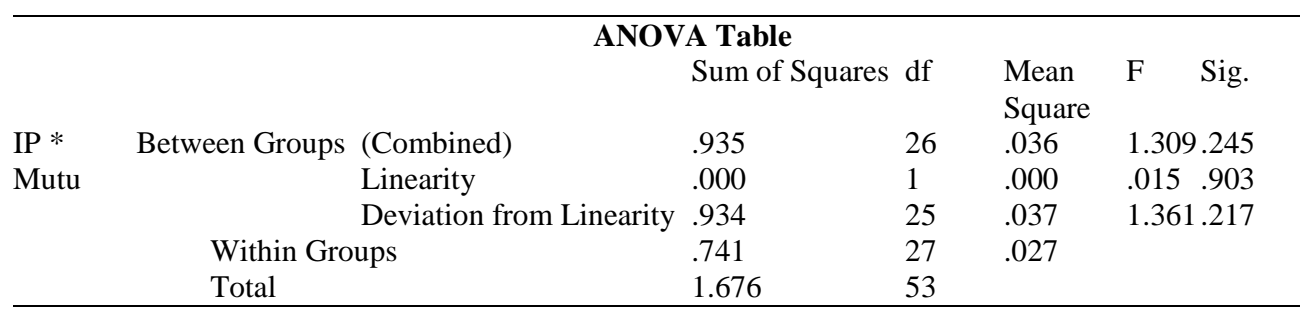

Based on the results of the linearity test, the sig value is known. $0.217>0.05$, it can be concluded that there is a linear relationship between IP and Quality of Learning Skills.

\section{Hypothesis Test}

Considering the requirements needed as a model of the relationship between variable $\mathrm{X}$ (the independent variable) and Y variable (the dependent variable) are fulfilled, the next analysis of the research hypothesis is carried out. 
Table 4. The interpreation of the correlation coefficient $r$ value[8]

\begin{tabular}{cc}
\hline coefficient interval & relationship level (category) \\
\hline $0.80-1,000$ & Very Strong \\
$0,60-0,799$ & Strong \\
$0,40-0,599$ & Strong Enough \\
$0,20-0,399$ & Low \\
$0,00-0,199$ & Very Low \\
\hline
\end{tabular}

Table 5. Multiple correlation test

\begin{tabular}{|c|c|c|c|c|c|c|c|c|}
\hline \multirow{3}{*}{ Model } & \multicolumn{8}{|c|}{ Model Summary } \\
\hline & $\mathrm{R}$ & $\mathrm{R}$ & Adjusted R & Std. Error of the & & Change Statistics & & \\
\hline & & Square & Square & Estimate & R Square Change & F Change df1 & $\mathrm{df} 2$ & Sig. F Change \\
\hline 1 & $.127^{\mathrm{a}}$ & .016 & -.023 & .17980 & .016 & .416 & 51 & .662 \\
\hline & edi & rs: $(\mathrm{C}$ & $\operatorname{tant}), \mathrm{Qu}$ & , Guidance & & & & \\
\hline
\end{tabular}

Based on the summary table it is known that the magnitude of the relationship between academic guidance and learning skills on learning achievement with a correlation coefficient of 0.127 , this shows a weak correlation. While the contribution or contribution of academic guidance variables and the quality of learning skills to learning achievement is $1.6 \%$ and $98.4 \%$ is determined by other factors. Then to find out the significance level of the multiple correlation coefficient tested overall with the hypothesis is:

Ha: Academic guidance and quality of learning skills are significantly related to learning achievement

Ho: Academic guidance and quality of study skills are not significantly related to learning achievement

Based on the summary model table, it was obtained that sig $=0.662$, because sig $\mathrm{F}>0.05$ then $\mathrm{Ha}$ was rejected and Ho was accepted meaning that there was no significant relationship between academic guidance and the quality of learning skills and learning achievement.

\section{References}

[1] J. Anidar, "Peran Penasehat Akademik Terhadap Kesuksesan Mahasiswa Di Perguruan Tinggi," Al-Ta lim, vol. 19, no. 3, p. 216, 2012.

[2] A. Muri Yusuf, Peran Penasehat Akademis dalam Menunjang Proses Perkuliahan Mahasiswa di Perguruan Tinggi. Padang, 1996.

[3] Kenneth C. Petress, "No Title The multiple roles of an undergraduate's academic advisor," Proj. Innov., vol. 117, no. 1, 1996.

[4] S. Yanti, N. Afni, and R. S. Samosir, "Analisa dan Perancangan Sistem Pembimbingan Akademik Institut Teknologi dan Bisnis Kalbe," vol. 5, no. 2, 2013.

[5] T. P. B. B. A. F. I. Bukittinggi, Buku Pedoman Bimbingan Akademik Untuk Mahasiswa. Bukittinggi, 2019.

[6] L. U. Martha K. Hemwall and F. \& M. C. Kent C. Trachte, "No Title Academic Advising as Learning: 10 Organizing Principles,” NACADA J., vol. 25, no. 2, pp. 74-83, 2005.

[7] I. dan I. Pulungan, Ensiklopedi Pendidikan, 1st ed. Medan: Media Persada, 2015.

[8] Riduwan, Belajar Mudah Penelitian untuk Guru-Karyawan dan Peneliti Muda. Bandung: Alfabeta, 2004. 